\title{
AS DIRETIVAS ANTECIPADAS DE VONTADE COMO CONDIÇÃO PARA AFERIR EM CONCRETO O MORRER COM DIGNIDADE À LUZ DA TEORIA DA EFICÁCIA IMEDIATA
}

\begin{abstract}
Janaína Reckziegel
Doutora em Direitos Fundamentais e Novos Direitos pela Universidade Estácio de Sá RJ, capital. Mestre em Direito Público pela Universidade de Caxias do Sul - Caxias do Sul, RS. Professora Universitária e Pesquisadora do Programa de Pós-Graduação em Direito da Universidade do Oeste de Santa Catarina (Unoesc) - Chapecó, SC. Editora de Seção da Revista Espaço Jurídico Journal of Law da Editora Unoesc (Qualis A2). E-mail: <janaina. reck@gmail.com>. Sistema Lattes: <http://lattes.cnpq.br/7597547217990217>.
\end{abstract}

\section{Beatriz Diana Bauermann Coninck}

Mestre em Direito no Programa de Pós-Graduação Stricto Sensu da Universidade do Oeste de Santa Catarina (Unoesc) - Chapecó, SC. Integrante do Projeto de Pesquisa em Direitos Fundamentais e Direitos Civis, em que desenvolve Dissertação sobre Direitos Fundamentais e Bioética sob a orientação da Professora Dra. Janaína Reckziegel. Advogada. Graduada pela Universidade Estadual do Oeste do Paraná (Unioeste) Cascavel, PR. E-mail: <mestrebeatriz123@hotmail.com>. Fone: (46) 8401-5023. Sistema Lattes: <http://lattes.cnpq.br/9733645795899329>.

\begin{abstract}
Resumo: Este artigo visa investigar se as diretivas antecipadas de vontade são condições ou pressupostos de manifestação do interessado, que tornem aferível e válida em concreto a sua pretensão de exercer o direito constitucional à morte digna, tomando como marco teórico a teoria da eficácia imediata. Para tanto, a dignidade da pessoa humana será estudada sob o enfoque filosófico, da ética médica e jurídica, no primeiro tópico; o segundo item abordará a teoria da eficácia imediata; e o terceiro ponto tratará das diretivas antecipadas de vontade e da possibilidade de esse recurso constituir um requisito de aferição concreta da dignidade humana em pacientes terminais sob a ótica da teoria da eficácia imediata. Aplicar-se-á o método dedutivo de abordagem qualitativa, partindo-se das noções gerais sobre a dignidade da pessoa humana, passando-se para a análise da referida teoria e as diretivas antecipadas, para, então, aplicá-las às situações de terminalidade da vida. Conclui-se que a teoria da eficácia imediata possibilita que a dignidade humana seja efetivada diante da morte inevitável de pacientes terminais ao realizarem as diretivas antecipadas, provando-se assim a sua utilidade concreta.
\end{abstract}

Palavras-chave: Dignidade da pessoa humana. Diretivas antecipadas de vontade. Teoria da eficácia imediata dos direitos fundamentais. Pacientes terminais.

Sumário: 1 Introdução - 2 A dignidade da pessoa humana pelo prisma da filosofia, da ética médica e jurídico - 3 Teoria da eficácia imediata dos direitos fundamentais - 4 Diretivas antecipadas de vontade, dignidade humana e teoria da eficácia imediata - $\mathbf{5}$ Considerações finais - Referências 


\section{Introdução}

Existem situações em que a morte é o desfecho do processo natural do viver. Em outras, a abreviação da vida pode ocorrer devido a um trauma físico, a uma parada cardiorrespiratória, ou em razão de enfermidade incurável. Há pacientes que padecem acamados em estado vegetativo por anos. Em muitos casos, o indivíduo toma conhecimento do seu diagnóstico quando não Ihe restam esperanças de cura, já próximo da terminalidade, momento em que a morte é inevitável e iminente e os tratamentos e terapias podem oferecer melhor qualidade de vida, ou simplesmente postergar o tempo de sobrevida e a morte.

Com o objetivo de valorizar a autonomia e a autodeterminação do paciente nos processos de tomada de decisão relativamente à sua saúde, as diretivas antecipadas de vontade foram planejadas para servir de registro prévio das disposições de vontade do paciente em relação à terapêutica necessária em momento futuro, mas que envolverão diretamente toda a equipe prestadora da assistência e os familiares do paciente, quando existirem, ultrapassando a mera relação bilateral entre médico e paciente. O tema engloba outros dilemas éticos como as práticas da eutanásia, da ortotanásia e do suicídio assistido e o embate sobre o morrer com dignidade e a dignidade da pessoa humana.

A teoria da eficácia imediata tem por escopo a defesa da aplicabilidade imediata dos direitos fundamentais nas relações entre particulares na medida em que compõem o núcleo do ordenamento jurídico e não apenas em face do Poder Público. A partir dessa teoria, as normas fundamentais são oponíveis independentemente de regulamentações legislativas e decisões judiciais, mediações legais e judiciais e possuem eficácia direta nas relações entre particulares.

No tocante à dignidade da pessoa humana, a médica e eticista americana Ruth Macklin ${ }^{1}$ rejeita a tese de que a dignidade teria utilidade prática, restando apenas o respeito pela autonomia pessoal. Segundo ela, os apelos em torno da dignidade não passam de reformulações vagas de outros conceitos ou meros lemas que em nada acrescentam para a compreensão do tema. Neste ponto, este breve escrito pretende analisar os conceitos e dimensões até então discutidos sobre a dignidade de modo a verificar, a partir de considerações filosóficas, bioéticas, biomédicas e jurídicas, a utilidade da dignidade da pessoa humana como limite para a prática médica imposto mediante a realização das diretivas antecipadas de vontade à luz da teoria da eficácia imediata dos direitos fundamentais.

MACKLIN, Ruth. Dignity is a useless concept. BMJ, v. 327, Dec. 2003. p. 1.419-20. 
Buscando descobrir se as diretivas antecipadas de vontade constituem condições ou pressupostos de manifestação do interessado aferiveis e válidos, em concreto, como pretensão de exercer o direito constitucional de morrer de forma digna, tomando como marco teórico a teoria da eficácia imediata, este artigo partirá dos enfoques filosóficos, bioéticos, médicos e jurídicos da dignidade da pessoa humana no primeiro tópico; o segundo item abordará a teoria da eficácia imediata; e o terceiro ponto responderá se as diretivas antecipadas de vontade são hábeis a averiguar concretamente a dignidade da pessoa humana em pacientes terminais, sob a ótica da teoria da eficácia imediata, de modo que a dignidade seja reconhecida como um fundamento útil, abstrato e concreto, para a realização das disposições de vontade do paciente.

\section{A dignidade da pessoa humana pelo prisma da filosofia, da ética médica e jurídico}

No pensamento ocidental, adotando a dimensão ontológica da dignidade humana, o maior expoente na temática da dignidade humana foi Immanuel Kant. ${ }^{2}$ Ele dizia que, em regra, todo ser humano racional existe como um fim em si mesmo e não um meio para os desígnios de outras vontades. A distinção entre pessoas e coisas reside no fato de que estas são seres irracionais, são meios e possuem valor relativo. As pessoas são seres racionais, portanto fins objetivos em si mesmos, não se cogitando a sua substituição por outros fins. As pessoas não têm preço como os seres irracionais, ou as coisas. ${ }^{3}$

Nesta esteira segue o imperativo prático kantiano “[...] age de tal maneira que tomes a humanidade, tanto em tua pessoa, quanto na pessoa de qualquer outro, sempre ao mesmo tempo como fim, nunca meramente como meio" que, levado a cabo, significa que se alguém pensar em tirar a própria vida deve perguntar-se se a sua ação leva a ideia de humanidade como uma finalidade em si mesma. Desse

2 Na opinião de Flademir Jerônimo Belinati Martins, no pensamento filosófico hodierno, o conceito de dignidade da pessoa humana tem prevalecido, sendo fonte a partir da qual muitos autores embasaram suas teses, inclusive constitucionais. A noção de pessoa racional kantiana é extraída da doutrina antropológica de Santo Tomás de Aquino. Kant afirmou que os seres irracionais são dotados de valor relativo, mas não de dignidade, qualidade intrínseca característica apenas dos seres racionais sem equivalente ou preço (MARTINS, Flademir Jerônimo Belinati. Dignidade da pessoa humana: princípio constitucional fundamental. 7. reimpr. Curitiba: Juruá, 2012. p. 25-29).

3 KANT, Immanuel. Fundamentação da metafísica dos costumes. Tradução com introdução e notas de Guido Antônio de Almeida. São Paulo: Barcarolla, 2009. p. 241. 
modo, ao servir-se de sua pessoa para escapar de uma situação difícil, estaria usando-a como um meio. O homem é um fim em si mesmo e não um mero meio. ${ }^{4}$

A moralidade está atrelada à ideia de liberdade. Não há como provar a liberdade como se fosse algo real ou da natureza do homem, ela é pressuposta da vontade em seres dotados de razão assim capacitados de representar-se em pensamento. ${ }^{5} \mathrm{~A}$ vontade pressupõe a liberdade sendo esta um atributo especial da vontade de todos os seres racionais. ${ }^{6}$ Se a vontade vale para todos os seres racionais e a liberdade é propriedade da vontade, logo, eles também são dignos da liberdade e de todas as leis a ela vinculadas. ${ }^{7}$

Em Metafísica dos costumes, Immanuel Kant alude ser a liberdade o único direito inato (o que ele chama de original por pertencer ao ser humano) e amplo. Ela é entendida como a "independência de ser constrangido pela vontade alheia", o que simboliza a possível coexistência com a liberdade das outras pessoas conforme uma lei universal. ${ }^{8}$

O que possibilita a autonomia é a liberdade e isso é um preceito moral. A autonomia é o escolher e o agir de acordo com a vontade boa em que o sujeito é um colegislador de leis universais às quais ele também se submete. A autonomia torna efetivas as determinações categóricas. O atuar moralmente depende dessa capacidade de autodeterminação do ser humano, tendo como fundamento os princípios autônomos escolhidos e determinados pelo próprio sujeito.

Na visão kantiana, o limite mais relevante à autonomia, isto é, à liberdade, refere-se à dignidade humana. O fundamento kantiano para a dignidade humana centra-se na autonomia e na autodeterminação da pessoa. A autonomia, um conceito abstrato, tem o papel de potencializar o ser humano no sentido da autodeterminação da conduta dispensando a sua efetiva concretização. A dignidade pensada por Immanuel Kant deve pertencer até mesmo aos destituídos de capacidade absoluta, como as pessoas incapazes física e/ou mentalmente. ${ }^{9}$

4 KANT, Immanuel. Fundamentação da metafísica dos costumes. Tradução com introdução e notas de Guido Antônio de Almeida. São Paulo: Barcarolla, 2009. p. 245.

5 KANT, Immanuel. Fundamentação da metafísica dos costumes. Tradução com introdução e notas de Guido Antônio de Almeida. São Paulo: Barcarolla, 2009. p. 357.

6 KANT, Immanuel. Fundamentação da metafísica dos costumes. Tradução com introdução e notas de Guido Antônio de Almeida. São Paulo: Barcarolla, 2009. p. 351.

7 KANT, Immanuel. Fundamentação da metafísica dos costumes. Tradução com introdução e notas de Guido Antônio de Almeida. São Paulo: Barcarolla, 2009. p. 353.

8 KANT, Immanuel. Metafísica dos costumes. Tradução, textos adicionais e notas de Edson Bini. São Paulo: Edipro, 2003. p. 83. Série Clássicos Edipro.

9 SARLET, Ingo Wolfgang. As dimensões da dignidade da pessoa humana: construindo uma compreensão jurídico-constitucional necessária e possível. In: SARLET, Ingo Wolfgang (Org.). Dimensões de dignidade: ensaios de filosofia do direito e direito constitucional. Tradução de Ingo Wolfgang Sarlet. Porto Alegre: Editora do Advogado, 2005. p. 21-22. 
Etimologicamente, autonomia significa "legislar para si". Pelo fato de a dignidade ser decorrente da liberdade e da autonomia, ela é objeto do dever moral. A autonomia, a liberdade e a dignidade formam uma tríade irrompível. ${ }^{10} \mathrm{~A}$ autonomia consiste no fundamento da dignidade humana de todo ser racional. ${ }^{11} \mathrm{~A}$ dignidade kantiana é entendida como um atributo inalienável do ser humano capaz de impedir que ele seja usado como coisa. A dignidade concretiza-se no indivíduo em virtude de sua capacidade de autodeterminação e racionalidade. ${ }^{12}$

Immanuel Kant doutrinou que todos devem respeito à lei, ou seja, à máxima de que toda pessoa deve ser considerada um fim e não um meio. É dever de cada um respeitar a própria dignidade e a alheia, pois dela derivam deveres. Se o indivíduo agir de forma indigna perde direitos fundamentais. Desse modo, se todo homem possui direito à vida, se houver legítima defesa, a morte de quem agride não pode ser considerada injusta; contraria a dignidade o ato de mutilar-se ou de humilhar os outros. ${ }^{13}$

O homem como fim em si mesmo precisa, ao mesmo tempo, escolher os próprios fins no sentido do que ele quer ser, mas também necessita atribuir-se um valor absoluto efetivado somente a partir do momento em que ele é capaz de ter uma vontade moralmente boa. Sendo a moralidade a condição única para um ser racional ser um fim em si mesmo, então se presume necessário, em primeiro lugar, supor antecipadamente o conceito de moralidade. Immanuel Kant entende que a natureza racional humana faz do homem pessoa, portanto, objeto do sentimento moral que é o sentimento de respeito. ${ }^{14}$

Entre os filósofos imanentistas, a dignidade foi apresentada como um atributo absoluto, prévio e transcendental. Immanuel Kant e Emmanuel Lévinas afirmaram que a liberdade, a autonomia e a racionalidade são devidas ao ser humano em virtude de sua dignidade. 0 primeiro compreendeu a dignidade como a

10 MAURER, Béatrice. Notas sobre o respeito da dignidade da pessoa humana... ou pequena fuga incompleta em torno de um tema central. In: SARLET, Ingo Wolfgang (Org.). Dimensões de dignidade: ensaios de filosofia do direito e direito constitucional. Tradução de Ingo Wolfgang Sarlet. Porto Alegre: Editora do Advogado, 2005. p. 76.

11 KANT, Immanuel. Fundamentação da metafísica dos costumes. Tradução com introdução e notas de Guido Antônio de Almeida. São Paulo: Barcarolla, 2009. p. 269.

12 RECKZIEGEL, Janaína; PEZZELA, Maria Cristina Cereser. O papel da sociedade tecnocientífica e os riscos decorrentes das pesquisas médicas com seres humanos. Revista Direitos Garantias Fundamentais, Vitória, v. 14, n. 2, p. 101-24, jul./dez. 2013. p. 114.

13 MAURER, Béatrice. Notas sobre o respeito da dignidade da pessoa humana... ou pequena fuga incompleta em torno de um tema central. In: SARLET, Ingo Wolfgang (Org.). Dimensões de dignidade: ensaios de filosofia do direito e direito constitucional. Tradução de Ingo Wolfgang Sarlet. Porto Alegre: Editora do Advogado, 2005. p. 83.

14 KANT, Immanuel. Fundamentação da metafísica dos costumes. Tradução com introdução e notas de Guido Antônio de Almeida. São Paulo: Barcarolla, 2009. p. 329-30. 
manifestação da magnitude humana, ao passo que o segundo buscou demonstrar que a dignidade se declara na fraqueza humana. ${ }^{15}$

A ética de Emmanuel Lévinas ${ }^{16}$ foi influenciada pela fenomenologia e tentou desenvolver a "fenomenologia da socialidade" desde o rosto do Outro que morre e que ordena que o Mesmo não haja com indiferença e não deixe o Outro sozinho, sendo assim a responsabilidade pela vida do Outro um responder ilimitado de alteridade ainda que seja somente para dizer: “eis me aqui". De acordo com o filósofo, ${ }^{17}$ o sujeito humano, ao que ele denomina de Mesmo (me) é chamado para a responsabilidade. A essência do ser ontológico não basta para a configuração da dignidade. O sujeito humano não consiste em um ser supremo da natureza ou um conceito, ele não pode ser reduzido à autoconsciência. Emmanuel Lévinas ${ }^{18}$ sustenta sua tese na ideia de que a responsabilidade precede a liberdade, na possibilidade de existência conjunta da liberdade do sujeito com o Outro sem que a liberdade deste seja ofendida. Para José André da Costa, ${ }^{19}$ a dignidade do Outro é respeitada quando é reconhecido como pessoa, em sua alteridade. ${ }^{20}$

Nas palavras de Emmanuel Lévinas, ${ }^{21}$ o sofrimento é um "conteúdo psicológico". Neste conteúdo, a consciência não significa a sua aceitabilidade. 0 fato de não assumir o sofrimento não advém do grau excessivo de uma sensação, nem decorre de uma quantidade excessiva da sensibilidade, contudo, o sofrimento é um "demais" que se entalha "num conteúdo sensorial, penetra como sofrimento nas dimensões do sentido que aí parecem abrir-se ou enxertar-se”. A dor, por seu

15 MAURER, Béatrice. Notas sobre o respeito da dignidade da pessoa humana... ou pequena fuga incompleta em torno de um tema central. In: SARLET, Ingo Wolfgang (Org.). Dimensões de dignidade: ensaios de filosofia do direito e direito constitucional. Tradução de Ingo Wolfgang Sarlet. Porto Alegre: Editora do Advogado, 2005. p. 66.

16 LÉVINAS, Emmanuel. Entre nós: ensaios sobre a alteridade. Tradução e coordenação de de Pergentino Stefano Pivatto. Petrópolis: Vozes, 2004. p. 217.

17 LÉVINAS, Emmanuel. Otherwise than being or beyond essence. Translated by Alphonso Lingis. Pittsburgh, Pennsylvania: Duquesne University Press, 2006. p. 18-19.

18 LÉVINAS, Emmanuel. Otherwise than being or beyond essence. Translated by Alphonso Lingis. Pittsburgh, Pennsylvania: Duquesne University Press, 2006. p. 123.

19 COSTA, José André da. Ética e política em Lévinas: um estudo sobre alteridade, responsabilidade e justiça no contexto geopolítico contemporâneo. 2011. 206 f. Tese (Doutorado em Filosofia) - Pontifícia Universidade Católica do Rio Grande do Sul, Porto Alegre, 2011. p. 18.

20 Lévinas volta-se contra os idealismos consubstanciados na razão, na dignidade e na racionalidade humana depois dos acontecimentos nos campos de concentração alemães. Com sua filosofia voltada para a vida, ele procurou analisar o ente em sua concretude, rejeitando tanto a ontologia hegeliana quanto a epistemologia idealista kantiana. o pensamento em Lévinas não se regra pela técnica já que pode desembocar no abandono do Outro. Ele propõe sua metafísica, fazendo distinção entre a "mesmidade" e a alteridade (COSTA, José André da. Ética e política em Lévinas: um estudo sobre alteridade, responsabilidade e justiça no contexto geopolítico contemporâneo. 2011. 206 f. Tese (Doutorado em Filosofia) - Pontifícia Universidade Católica do Rio Grande do Sul, Porto Alegre, 2011. p. 37-39).

21 LÉVINAS, Emmanuel. Entre nós: ensaios sobre a alteridade. Tradução e coordenação de de Pergentino Stefano Pivatto. Petrópolis: Vozes, 2004. p. 164. 
turno, enquanto “desordena a ordem”, é “o próprio desordenamento". A dor é o rejeitar em si, não se tratando apenas da tomada de consciência ou do sintoma de uma rejeição. O sofrimento também é passividade, uma qualidade que não é o oposto de atividade, vai além, é muito mais passiva do que a própria atividade receptora dos sentidos e supera a própria percepção. O sofrimento também demonstra a vulnerabilidade que supera tanto a receptividade como a experiência. "O sofrer é um padecer puro". O sofrimento é o mal. A dor também é um mal, a dor é o dano em si.

Intrinsecamente falando, o sofrimento é um fenômeno inútil, isto é, "por nada" - vide as experiências de dores persistentes e intratáveis nos relatos médicos de pacientes com nevralgias, lombalgias e tumores malignos. Essas são denominadas “dores-doenças", em que a dor se transforma no principal fenômeno vivido pelo enfermo, podendo levar à piora do quadro, elevando a "crueldade do mal", se os pacientes também forem abandonados e se sentirem angustiados. Os seres retardados, que já possuem estreitamento em suas relações, encaixam-se no grupo daqueles que sentem a "dor pura", dentro da categoria das "doresdoenças". Nestes casos, a "dor pura” que neles se manifesta projeta-se no Mesmo (eu), suscitando um problema ético da medicação - quando "o mal do sofrimento" passivo, impotente, abandonado e só é assumido e, como não está integrado, o seu rogo por socorro e por cura se manifesta por meio de "um gemido", "um grito”, “uma queixa”, “um suspiro”; uma súplica pela analgesia e pela urgente eliminação da dor parece ser mais emergente do que "um pedido de consolação ou de adiamento da morte”, em uma relação de alteridade ética, médica, obstinada e fundamental. A medicina, nessas conjecturas, com sua técnica e tecnologia não se comporta somente como "vontade de poder". ${ }^{22}$

Em verdade, as doutrinas de Immanuel Kant e Emmanuel Lévinas respaldaramse na prioridade da ética da vida como forma de expressão da dignidade humana, mostrando, neste ponto, o resgate do pensamento kantiano pelo pensamento levinasiano. Emmanuel Lévinas, contudo, desviou-se do kantismo ao defender a responsabilidade pelo Outro e afastando-se da representação de sofrimento dada por Immanuel Kant. Este afirmava ser a racionalidade humana ("o que") um traço peculiar do ser humano, conferindo-Ihe semelhança a Deus. Emmanuel Lévinas ocupou-se do Outro ("quem"), argumentando que o Outro não se reduz a elementos como a razão ou a linguagem. A alteridade não se funda na propriedade. ${ }^{23}$

22 LÉVINAS, Emmanuel. Entre nós: ensaios sobre a alteridade. Tradução e coordenação de de Pergentino Stefano Pivatto. Petrópolis: Vozes, 2004. p. 130-131.

23 PERPICH, Diane. The ethics of Emmanuel Lévinas. Califórnia: Stanford University Press, 2008. p. 153154. 
A dignidade para Andrés Felipe Thiago Selingardi Guardia ${ }^{24}$ é a reunião de valores. Ele compreende o homem como "um plexo de valores ônticos e não ônticos", por consequência, a dignidade é esse "conjunto de valores". A dignidade não é composta de valores morais, estéticos e físicos, pois eles variam entre os sujeitos e são não ônticos. Os valores ônticos que compõem a dignidade são o de cada ser humano por ser homem. Em sua opinião, ${ }^{25}$ homem, pessoa e dignidade formam uma realidade única e formam um ser único de dignidade. Não se fala em dignidade da "pessoa" humana, mas em dignidade do homem. Este homem que não pode ser instrumentalizado, pois ele vai criar o direito. Os valores são medidas de perfeição que se descobre com a experiência ou intuição. O valor está concretamente representado no ser, mas transcende a sua existência própria. A dignidade não consiste em uma "ficção jurídica", nem algo abstrato inventado pelo legislador. Ela "não é um valor humano, mas o conjunto de valores ônticos encerrados no homem”. O direito é uma criação do homem, todavia a dignidade não. As normas são pensadas para resguardar a dignidade do homem, sendo função do Estado oferecer meios de protegê-la. A dignidade não é infinita, contudo os valores sim. São dinâmicos no tempo e no lugar e devem ser usados para proteger a dignidade do homem e este por si.

No contexto da bioética médica, as opiniões divergem, predominando, contudo, os fundamentos e conceitos filosóficos na questão da dignidade. A médica americana Ruth Macklin ${ }^{26}$ rejeita a tese da utilidade da dignidade. Para a eticista, a dignidade é um conceito inútil, significando nada mais que respeito pelas pessoas em sua autonomia, e os apelos em torno da dignidade, na análise dos principais exemplos, não passam de reformulações vagas de outros conceitos ou meros lemas que em nada acrescentam para a compreensão do tema. Relativamente à medicina e à biologia, são poucas as referências ao tema nas declarações de direitos humanos. Entre elas, a Convenção do Conselho da Europa dirigida aos Direitos Humanos e à Dignidade, cujo teor aborda a dignidade simplesmente como respeito pelas pessoas, no contexto do consentimento informado e voluntário, e a indispensável necessidade de evitar o abuso e a discriminação, bem como resguardar a confidencialidade.

24 GUARDIA, Andrés Felipe Thiago Selingardi. A dignidade da pessoa humana: da antropologia filosófica ao Estado Democrático de Direito. Revista Faculdade de Direito da Universidade de São Paulo, v. 109, p. 217-44, jan./dez. 2014. p. 221-229.

25 GUARDIA, Andrés Felipe Thiago Selingardi. A dignidade da pessoa humana: da antropologia filosófica ao Estado Democrático de Direito. Revista Faculdade de Direito da Universidade de São Paulo, v. 109, p. 217-44, jan./dez. 2014. p. 232-239.

26 MACKLIN, Ruth. Dignity is a useless concept. BMJ, v. 327, Dec. 2003. p. 1.419. 
Na opinião da autora, ${ }^{27}$ foram os questionamentos acerca do processo de morrer, traduzidos no "direito de morrer com dignidade", especialmente quanto à vontade de renunciar a tratamentos médicos que prolongam a vida, aflorados na década de 1970, que levaram ao reconhecimento do direito de os pacientes realizarem as diretivas antecipadas que acabaram resultando no California Natural Death Act, de 1976. Nesse documento, a dignidade e a privacidade da pessoa foram reconhecidas com o direito de um adulto de fazer, por escrito, as diretrizes orientadoras da atuação médica, especialmente quanto à recusa de procedimentos de sustentação vital na hipótese de terminalidade. O significado de dignidade, segundo Macklin, não passa de respeito pela autonomia. Por conseguinte, não há sentido na crítica de certos eticistas de que se estaria violando a dignidade do morto através da conduta acadêmica de permitir o treino de procedimentos em cadáveres pelos estudantes de medicina. Isso porque, segundo ela, desconsiderando o interesse familiar pelo falecido, o respeito, nesse caso, é pelos desejos dos vivos. Assim, a eliminação do conceito em nada prejudicaria o conteúdo.

Em Adam Schulman, ${ }^{28}$ por sua vez, a dignidade humana possui um conceito flexível, maleável, de aplicação indeterminada na bioética. A explicação, em parte, radica já nas diferenças em suas origens que remontam à Antiguidade clássica, em que os gregos (dignus) ${ }^{29}$ e romanos (dignitas) viam-na como algo raro e insólito presente no desempenho atlético e musical, no heroísmo na guerra e no altruísmo dos que se sacrificavam por suas crianças, idosos e vizinhos acometidos por alguma desventura ou tragédia. Para os estoicos, o predicado da dignidade vinculavase a todos os seres humanos em função de sua racionalidade, cuja função era proporcionar paz à mente. A pobreza, a opressão e a doença não deveriam impedir

27 MACKLIN, Ruth. Dignity is a useless concept. BMJ, v. 327, Dec. 2003. p. 1.419-1.420.

28 SCHULMAN, Adam. Bioethics and the question of human dignity. In: SCHULMAN, Adam (Ed.). Human dignity and bioethics: Essays Commissioned by the President's Council on Bioethics. Washington, D.C.: [s.n.], 2008. p. 6-12.

29 Aristóteles via a morte como a mais terrivel de todas as coisas considerando-a o fim e, aos mortos, nada de bom ou mau. Bravo seria aquele que desteme a morte honrosa e covarde aquele que prefere a morte para fugir da pobreza, de um amor ou outro motivo (ARISTÓTELES. Ética a Nicômaco. Seleção de textos de José Américo Motta Pessanha. 4. ed. São Paulo: Nova Cultural, 1991. p. 60. v. 2. Coleção Os Pensadores).

Segundo Martins, os gregos não empregavam de forma direta a ideia de dignidade da pessoa humana. A grande contribuição grega foi no pensamento racional e no atuar humano, superando o pensamento mítico. A filosofia cristã contribuiu ao transmitir a igualdade entre todos os homens e o respeito pela sua dignidade intrínseca. Apesar disso, foi São Tomás de Aquino quem mencionou, pela primeira vez, a expressão "dignidade humana” vinculada à acepção de pessoa cuja racionalidade, atributo peculiar dos seres humanos, conferindo-lhes liberdade, porém acompanhada de responsabilidade. O ser humano passa a ser visto como um fim e si (MARTINS, Flademir Jerônimo Belinati. Dignidade da pessoa humana: princípio constitucional fundamental. 7. reimpr. Curitiba: Juruá, 2012. p. 20-24). 
o viver digno. A religião bíblica professava o homem como imagem e semelhança de Deus, por isso a inalienabilidade e inerência da dignidade do homem.

A filosofia moral kantiana, com base no estoicismo, tentou universalizar a dignidade humana pela sua autonomia racional. 0 respeito pela dignidade era compreendido como a proibição de manipular as pessoas, como meios, objetos e instrumentos. O problema com a teoria de Immanuel Kant, para Adam Schulman, reside na dificuldade de aplicá-la, na prática biomédica, aos casos de demência, de crianças e pessoas com problemas mentais congênitos, desprovidos de autonomia racional formada, ou que a tenha perdido ou nunca a tenha possuído, que seriam carentes de dignidade. Outro problema apontado pelo autor, para a bioética relativamente à dignidade, é que as fontes constantes das constituições do século XX e as declarações internacionais trazem fundamentos norte-americanos sobre a vida, a liberdade e a dignidade, esta inalienável e inerente ao ser humano.

Adam Schulman, ${ }^{30}$ de índole liberal, posiciona-se favorável à existência da dignidade como humanidade, isso porque, desde Hobbes e Locke até os fundadores americanos, por motivos políticos e por prudência, outrora asseveraram que a dignidade pertence a todos os seres humanos. O fundamento da dignidade, para ele, contempla a promoção da tolerância, da liberdade, da paz e da igualdade e, no espaço da ética médica, do respeito pelos demais, bem como da confidencialidade, da voluntariedade, do consentimento informado, e da defesa contra o abuso e a discriminação. Diante do poder de manipulação do homem sobre a sua natureza através da biotecnologia, não se poderia negar a existência da dignidade no sentido de humanidade.

Timothy Caufield e Audrey Chapman ${ }^{31}$ alertam que o impasse em torno da dignidade é devido à sua vagueza e pobreza conceitual. As maiores complicações são observadas em sociedades plurais nas quais a diversidade de grupos e de comunidades expressam o seu conceito de dignidade esculpido e orientado por seus valores religiosos, entendimentos culturais e visões do mundo. Eles advertem que o modelo de dignidade apresentado em documentos que tratam de questões científicas controvertidas, como do genoma humano e de célulastronco, salienta o direito dos indivíduos de fazerem escolhas autônomas tratando a dignidade humana como um meio de empoderamento. Ao invés disso, o melhor caminho seria interpretá-la como um meio de restrição que está ganhando espaço salutar na política científica. Em outros casos, como o da mercantilização de

30 SCHULMAN, Adam. Bioethics and the question of human dignity. In: SCHULMAN, Adam (Ed.). Human dignity and bioethics: Essays Commissioned by the President's Council on Bioethics. Washington, D.C.: [s.n.], 2008. p. 15-17.

31 CAULFIELD, Timothy; CHAPMAN, Audrey. Human dignity as a criterion for science policy. PLoS Medicine, v. 2, n. 8, p. 736-8, ago. 2005. p. 736-737. 
tecidos, de clonagem humana e para aqueles que se opõem às pesquisas com células-tronco, ou buscam limitar pesquisas com embriões humanos, a dignidade espelha uma posição moral ou social, no sentido de que essas atividades são contrárias à moralidade pública ou ao bem coletivo. Muito embora exista uma ideia comum de que a dignidade é algo inerente ao ser humano, esses documentos refletem que ela depende de valores e da experiência dos indivíduos dentro de suas sociedades. Ademais, nas sociedades pluralísticas, o problema seria como alcançar um consenso sobre a dignidade se nem se chegou a um fundamento unívoco de dignidade, se profano ou baseado na fé. Mais complicado ainda seria chegar a um consenso sobre o que ela relaciona e obter uma ideia universal, isso porque existem opiniões particulares que talvez nem representem a maioria.

Roger Brownsword ${ }^{32}$ pondera sobre a transformação da bioética calcada no debate entre utilitaristas e os defensores dos direitos humanos. A bioética, contudo, reúne esses lados num terceiro ponto, na “aliança dignitária”. Não é possível sustentar os direitos humanos no princípio do respeito pela dignidade, nem se pode usar a linguagem da dignidade humana para retratar essa nova aliança, dado o valor unificador da proteção da dignidade humana na relação. Há duas deontologias sobre a dignidade humana na bioética: a) autonomia como empoderamento, no apoio à autonomia individual; e b) autonomia como restrição. Nenhuma das duas vertentes oferece embasamentos suficientes a sustentar a dignidade humana.

No caso da "morte com dignidade", tanto a autonomia como empoderamento quanto a autonomia como restrição advogam pelo respeito à dignidade humana, quer seja por aqueles que defendem a morte digna, quer seja pelos opositores da ideia. A dignidade como empoderamento está fortemente relacionada com a sabedoria dos direitos humanos modernos. Ela aparece em várias cartas de direitos humanos, como a Declaração Universal dos Direitos Humanos de 1948, afirmando ser um direito inerente e inalienável dos seres humanos igual e universalmente. Essa não é, contudo, uma afirmativa convincente para todos os seres humanos. ${ }^{33}$

Deixando de lado os argumentos utilizados por cada movimento na defesa de sua tese, verifica-se como elemento convergente o respeito pela dignidade humana. A dignidade humana como empoderamento protege a autonomia na tomada de decisão, sublinhando que só assim se pode exercer a dignidade. Agentes autônomos podem sobrepor suas decisões sobre as restrições do grupo

32 BROWNSWORD, Roger. Bioethics today, bioethics tomorrow: stem cell research and the dignitarian alliance. 17 Notre Dame J. L. Ethics \& Pub. Pol'y, n. 15, p. 15-51, 2003. p. 18-20.

33 BROWNSWORD, Roger. Bioethics today, bioethics tomorrow: stem cell research and the dignitarian alliance. 17 Notre Dame J. L. Ethics \& Pub. Pol'y, n. 15, p. 15-51, 2003. p. 18-20. 
ou individuais, a ponto de essas pessoas controlarem um espaço, um país. Por outro lado, na comunidade guiada pela dignidade como restrição, respeita-se um conjunto de valores protegidos pela noção de dignidade humana. Se determinado grupo simular o entendimento de dignidade do outro grupo, haverá algum grau de correspondência prática entre esses grupos bioéticos de maneira que modelos possam ser aceitos e aplicados em cada grupo. Deve-se sempre levar em conta que as crenças básicas sobre a dignidade humana são distintas para ambas as comunidades bioéticas. A ideia é a de que haja uma correspondência entre ambas as perspectivas e que a bioética prática possa levar a acordos. ${ }^{34}$

Hans Jonas ${ }^{35}$ critica o controle da conduta humana por meio das ciências médicas que substituem artificialmente o agir humano. Em sua opinião, não se questionam os benefícios, por exemplo, da utilização da técnica médica a fim de tirar sintomas dolorosos dos enfermos mentais, contudo, não é louvável fazer dessas técnicas como forma de conforto e manipulação social, afetando os direitos e a dignidade humana. Toda vez que a prática humana, ao lidar com os problemas humanos, for substituída por mecanismos impessoais, alguma coisa da dignidade da pessoa também é suprimida e se transfere mais a responsabilidade dos agentes para "sistemas programados de comportamento". Os benefícios da "empresa humana" de controle social devem ser avaliados, axiologicamente, frente ao sacrifício da privação da autonomia individual.

A morte, outrossim, possui a própria dignidade, e é direito humano deixá-la seguir o seu curso normal. ${ }^{36} \mathrm{O}$ direito de morrer não se confunde com o suicídio. 0 direito de morrer sim está atrelado à condição daquele paciente que se encontra em estado mortal e vulnerável à medicina moderna materializada nas técnicas de retardamento da morte. ${ }^{37}$

Pelo prisma jurídico-constitucional, Ingo Wolfgang Sarlet ${ }^{38}$ conceitua a dignidade da pessoa humana como um atributo intrínseco, diferenciado e reconhecido de todo ser humano capaz de fazer dele um merecedor de respeito e consideração, seja pela comunidade seja pelo Estado. O ser humano deve ser protegido contra atos de degradação e condutas desumanas e ter garantidas as

34 BROWNSWORD, Roger. Bioethics today, bioethics tomorrow: stem cell research and the dignitarian alliance. 17 Notre Dame J. L. Ethics \& Pub. Pol'y, n. 15, p. 15-51, 2003. p. 18-20. p. 31-32.

35 JONAS, Hans. El principio de responsabilidad: ensayo de una ética para la civilización tecnológica. Introdución de Andrés Sánchez Pascual. Barcelona: Herder, 1995. p. 53.

36 JONAS, Hans. El principio de responsabilidad: ensayo de una ética para la civilización tecnológica. Introdución de Andrés Sánchez Pascual. Barcelona: Herder, 1995. p. 155-156.

37 JONAS, Hans. El principio de responsabilidad: ensayo de una ética para la civilización tecnológica. Introdución de Andrés Sánchez Pascual. Barcelona: Herder, 1995. p. 160.

38 SARLET, Ingo Wolfgang. Dignidade da pessoa humana e direitos fundamentais na Constituição Federal de 1988. 7. ed. rev. e atual. Porto Alegre: Livraria do Advogado, 2009. p. 67-83. 
mínimas condições existenciais para uma vida saudável. Além disso, é preciso a viabilização e promoção da própria e responsável participação nos caminhos de sua vida existencial, em comunhão com os outros seres humanos, imperando o respeito mútuo. A dignidade é um valor (um princípio) passível de ponderação e de relativização, e insubstituível. Para o autor, ${ }^{39}$ a dignidade atrai e exige a proteção de todos os direitos fundamentais.

A concepção principiológica da dignidade da pessoa humana como princípionorma imprime o atributo de submetê-la a certa relativização, preservado, contudo, o seu núcleo essencial que é intangivel. Nos moldes kantianos, consiste no ponto intocável traduzido na não coisificação ou instrumentalização da pessoa. $A$ dignidade não pode ser ofendida nem mesmo com o fim de tutelar a dignidade de terceiros (tortura, por exemplo). É preciso tolerância em sociedades multiculturais, pois à dignidade podem ser atribuídos conceitos discrepantes, produzindo resultados heterogêneos. A abertura conceitual da dignidade está associada a relações e ações comunicativas envolvendo aspectos históricos e culturais. ${ }^{40}$

Robert Alexy, ${ }^{41}$ baseando-se na Constituição alemã, argumenta que pelo fato de o princípio da dignidade humana ser em parte princípio e em parte regra, e, em razão de a dignidade atrair um amplo grupo de precedências garantindo ao princípio dignidade um alto grau de segurança frente a outros princípios, transmite a impressão de ser um princípio absoluto. O Tribunal Constitucional Federal alemão conceitua a dignidade da pessoa humana como a "esfera nuclear da configuração da vida privada, protegida de forma absoluta". Nas situações de fato relevantes, não há prevalência da dignidade humana sobre outras normas, mas somente se busca averiguar a sua possível violação. Contudo, em virtude da abertura conceitual da dignidade, a sua definição depende das circunstâncias do caso concreto de sorte que precisa de sopesamento. Da preponderância do princípio da dignidade humana sobre outros princípios resulta o produto, o conteúdo da regra, esta sim absoluta.

Como se percebe, existe farta doutrina sobre a dignidade humana, o que não ocorre, contudo, no ordenamento jurídico interno, tal como acontece com a expressão "vida". O legislador pátrio não ousou apresentar definição da dignidade, limitando-se a adjetivá-la como um fundamento ${ }^{42}$ constitucional.

39 SARLET, Ingo Wolfgang. Dignidade da pessoa humana e direitos fundamentais na Constituição Federal de 1988. 7. ed. rev. e atual. Porto Alegre: Livraria do Advogado, 2009. p. 94.

40 SARLET, Ingo Wolfgang. Dignidade da pessoa humana e direitos fundamentais na Constituição Federal de 1988. 7. ed. rev. e atual. Porto Alegre: Livraria do Advogado, 2009. p. 148-151.

41 ALEXY, Robert. Teoria dos direitos fundamentais. Tradução de Virgílio Afonso da Silva. São Paulo: Malheiros, 2008. p. 111-114.

42 A noção de fundamento implica o estudo do desenvolvimento de princípio para fundamento. Aristóteles empregava o termo "princípio" como indicativo de algo que se desenvolve e evolui. Em Kant (1993), na 


\section{Teoria da eficácia imediata dos direitos fundamentais}

Não é pacífica a maneira pela qual os direitos fundamentais incidem nas relações privadas, tampouco o seu grau de incidência. Para a concepção tradicional dos direitos fundamentais, os particulares só podem opor-se aos poderes públicos, isso porque as primeiras declarações de direitos humanos, ao final do século XVIII, surgiram como reação ao Estado absolutista, buscando-se proteger a sociedade civil, a partir da proteção das liberdades individuais. ${ }^{43}$

A constitucionalização do direito ocorre após o desenrolar de várias declarações de direitos humanos. Em razão das violações a esses direitos na primeira metade do século XX, mudou-se a antiga visão sobre o direito privado, notadamente entre os alemães, embora incerta a eficácia desses direitos nas relações horizontais. Mais especificamente, a eficácia dos direitos fundamentais nas relações entre particulares é acentuada a partir da segunda metade do século XX, aprofundando-se no século XXI. ${ }^{44}$

A teoria dos efeitos indiretos ou mediatos é uma proposição interposta entre a teoria do state action, que rejeita a vinculação dos direitos fundamentais às relações privadas, e a que propugna pela tese de eficácia imediata ou direta desses direitos no âmbito privado. Aquela é preferida pela doutrina majoritária e, em ampla medida, pelo Tribunal Constitucional Alemão. Os argumentos da vertente teórica de eficácia mediata elevam o direito geral de liberdade, no afã de harmonizar o direito privado e o direito constitucional, sem preponderância deste sobre aquele. ${ }^{45}$

Crítica da razão pura, o fundamento é um raciocínio jurídico de buscar as justificativas que legitimam a sua conclusão. Na seara fática, o profissional do direito se debruça sobre provas. Por isso Kant escreveu os Fundamentos para uma metafísica dos costumes, procedendo a uma dedução transcendental na área da ética que, em verdade, é uma justificativa para as ações humanas, traduzida como o imperativo categórico que é o princípio supremo da mortalidade, ou seja, o fundamento que determina a vontade. Aristóteles falava em "fonte" enquanto em Kant, "razão justificativa". Na Constituição de 1988, a dignidade humana vem como "fundamento", simbolizando a fonte legitimadora ou razão justificativa. Para a teoria geral do direito, "fundamento" transmite a ideia de "validade" e de fonte dos efeitos que emanam das normas. 0 poder constituinte encontra fundamentos em fatos e princípios éticos. 0 grande problema com o positivismo foi buscar um fundamento além da simples validade formal normativa, sendo que o fundamento depende de um valor ético do direito. O direito é uma invenção humana, decorrendo desse humano seu valor. É um engano pensar que direitos historicamente relativos não podem ter fundamento absoluto (COMPARATO, Fábio Konder. Fundamento dos direitos humanos. Instituto de Estudos Avançados da Universidade de São Paulo, p. 1-21, 2013. p. 1-7).

43 CARBONELL, Miguel. Derechos fundamentales y relaciones entre particulares (notas para su estúdio). IUS - Revista del Instituto de Ciencias Jurídicas de Puebla A.C., México, n. 18, p. 50-75, 2006. p. 50.

44 FREITAS, Riva Sobrado de; CLEMENTE, Alexandre Shimizu. A incidência dos direitos fundamentais nas relações privadas. Direitos Fundamentais \& Justiça, ano 5, n. 15, p. 159-185, abr./jun. 2011. p. 160161.

45 FREITAS, Riva Sobrado de; CLEMENTE, Alexandre Shimizu. A incidência dos direitos fundamentais nas relações privadas. Direitos Fundamentais \& Justiça, ano 5, n. 15, p. 159-185, abr./jun. 2011. p. 169. 
O pilar da teoria da eficácia mediata é a preservação da autonomia privada como forma de contestação à teoria da eficácia imediata. Naquela, os direitos fundamentais interferem mediatamente nas relações jurídicas entre particulares, mais especialmente nas modalidades fortes, isso justifica a restrita aplicação dos direitos fundamentais à autonomia privada na esfera dos contratos, por exemplo. Através de regulamentações legislativas específicas e por intermédio da atividade judicial, essa teoria prefere as cláusulas gerais de direito privado, recheadas de conotação axiológica que subjaz aos direitos fundamentais, e que são importantes ao caso concreto. ${ }^{46}$

A proposta de Dürig é pela incidência dos direitos fundamentais sobre o direito privado, contudo a partir de conceitos indeterminados e das cláusulas gerais emanadas do próprio direito privado, construindo, assim as próprias normas. Nesse sentido, os valores constitucionais atingem as normas privadas através de "pontes", de sorte que os direitos fundamentais figuram como um "sistema de valores" ou "ordem objetiva de valores" irradiados para todo o ordenamento jurídico, invadindo o direito privado pelas cláusulas gerais e conceitos indeterminados. A aplicação dos direitos fundamentais é mediada por legislador ordinário, cabendo ao Judiciário complementar as cláusulas gerais com o fundamento valorativo dos direitos fundamentais. ${ }^{47}$

A teoria da eficácia imediata, ou teoria da eficácia direta, atualmente preferida em Portugal e Itália, mais especialmente na Espanha, ${ }^{48}$ nasceu na Alemanha com Nipperdey, que defendeu mais sistematicamente a eficácia dos direitos humanos em face de terceiros (Drittwirkung der Grundrechte). Sua teoria foi abraçada pelo Tribunal Laboral alemão, recebendo apoio e críticas de muitos estudiosos do direito público, embora encontre adesão progressiva em muitos tribunais. ${ }^{49}$

Utilizada pelo Supremo Tribunal Federal, um dos aspectos destacáveis desta teoria é a não exigência de “pontes" de comunicação entre os direitos fundamentais e o direito privado. Isso em virtude de aqueles consistirem em "verdadeiros direitos subjetivos" dos particulares em suas interações, de modo que esses particulares possam socorrer-se dos direitos fundamentais frente a seus direitos violados. Os defensores dessa teoria acreditam no procedimento da

46 STEINMETZ, Wilson. A vinculação dos particulares a direitos fundamentais. São Paulo: Malheiros, 2004. p. 197.

47 FREITAS, Riva Sobrado de; CLEMENTE, Alexandre Shimizu. A incidência dos direitos fundamentais nas relações privadas. Direitos Fundamentais \& Justiça, ano 5, n. 15, p. 159-185, abr./jun. 2011. p. 169170.

48 STEINMETZ, Wilson. A vinculação dos particulares a direitos fundamentais. São Paulo: Malheiros, 2004. p. 164.

49 FERNÁNDEZ DEL CASTILLO, Tomás de la Quadra Salcedo. Derecho público, derecho privado y derechos fundamentales. Revista General de Derecho Administrativo, n. 34, p. 1-66, 2013. p. 7. 
ponderação entre a autonomia privada e os direitos fundamentais como forma de resolver os conflitos da relação. ${ }^{50}$

Segundo Nipperdey, os direitos fundamentais são dotados de efeitos jurídicos que mais se aproximam de efeitos normativos absolutos sobre o direito privado, ainda que as normas privadas sejam cogentes, cláusulas gerais, direitos subjetivos ou deveres. As normas de direitos fundamentais são objetivas e vinculantes. Dos próprios princípios é que brotam os direitos subjetivos privados aos indivíduos. ${ }^{51}$

O mais relevante embaraço à teoria da eficácia imediata nas relações entre particulares ocorreu em torno da autonomia privada, atribuindo àquela uma ação intimidadora sobre o próprio direito privado, especialmente ao direito civil, o qual chegaria a perder sua autonomia e sua identidade perante o direito constitucional. ${ }^{52}$

Como as diretivas antecipadas de vontade estão diretamente vinculadas às situações existenciais, o próximo tópico versará sobre o seu possível ajustamento como uma condição para cotejar concretamente a dignidade humana em pacientes terminais à luz da teoria da eficácia imediata.

\section{Diretivas antecipadas de vontade, dignidade humana e teoria da eficácia imediata}

O debate sobre o assunto das diretivas antecipadas de vontade chama atenção para as situações existenciais. Meireles ${ }^{53}$ diferencia as situações que têm função social daquelas que são a própria função social, isso a depender do interesse social e do interesse individual considerado. Nas circunstâncias jurídicas em que inexiste uma divisão entre o interesse individual e a função social, como as "situações existenciais", tem-se a função social em si - isso porque a pedra angular é a dignidade humana de interesse individual e coletivo. "As situações jurídicas subjetivas existenciais" envolvem a tutela da pessoa com vistas à promoção da dignidade humana e ao desenvolvimento da personalidade.

0 art. 11 do Código Civil brasileiro disciplina os atributos dos direitos de personalidade, abarcando não somente esses, mas as "situações subjetivas existenciais", cujas normas preveem a sua intransmissibilidade e irrenunciabilidade,

50 FREITAS, Riva Sobrado de; CLEMENTE, Alexandre Shimizu. A incidência dos direitos fundamentais nas relações privadas. Direitos Fundamentais \& Justiça, ano 5, n. 15, p. 159-185, abr./jun. 2011. p. 172.

51 ALEXY, Robert. Teoria dos direitos fundamentais. Tradução de Virgílio Afonso da Silva. São Paulo: Malheiros, 2008. p. 530.

52 STEINMETZ, Wilson. A vinculação dos particulares a direitos fundamentais. São Paulo: Malheiros, 2004. p. 187.

53 MEIRELES, Rose Melo Vencelau. Autonomia privada e dignidade humana. Rio de Janeiro: Renovar, 2009. p. 44-45. 
além da impossibilidade de serem limitados voluntariamente. A disposição autônoma de direitos envolvendo questões existenciais resulta na constituição, modificação ou extinção de uma relação jurídica. ${ }^{54}$

Em apertada síntese, o modelo norte-americano de diretivas antecipadas de vontade constitui uma forma de manifestação do interessado de deixar registrada, antecipadamente, a sua vontade traduzida na escolha de tratamentos ou terapias a que deseja se submeter no futuro quando estiver enfermo, ou seja, quanto à utilização de consentimento próprio para recusar, desistir ou aceitar procedimentos relativos à sua saúde em momento vindouro. As diretivas são compostas de duas espécies: as declarações prévias (testamento vital) e o mandato vindouro. As primeiras ditam as diretrizes no tocante a intervenções médicas, ao passo que o segundo diz respeito à eleição de um futuro cuidador (mandatário) dos interesses do interessado (mandante) quando estiver na condição de enfermo e se encontrar incapacitado para expressar de forma válida o seu consentimento. ${ }^{55}$

As declarações prévias são uma espécie de negócio jurídico unilateral não receptício ${ }^{56}$ em que dispensa a vontade do destinatário para produzir efeitos, gratuito, inter vivos, informal, principal, personalíssimo e sujeito a nulidades. $\mathrm{Na}$ base estruturante do sistema dos fatos jurídicos estão os requisitos de existência. Em verdade, como o Código Civil não adotou o modelo de Pontes de Miranda, os requisitos ou elementos existenciais que estruturam o negócio jurídico são a "declaração de vontade, a finalidade negocial ${ }^{57}$ e a idoneidade do objeto". ${ }^{58}$

54 MEIRELES, Rose Melo Vencelau. Autonomia privada e dignidade humana. Rio de Janeiro: Renovar, 2009. p. $151-154$.

55 GODINHO, Adriano Marteleto. Diretivas antecipadas de vontade: testamento vital, mandato duradouro e sua admissibilidade no ordenamento jurídico brasileiro. Instituto de Direito Brasileiro, Lisboa, ano 1, n. 2, p. 945-978, 2012.

56 A declaração receptícia visa ao conhecimento do ato pelo destinatário, para que produza os seus devidos efeitos, ou seja, para que haja o acordo de vontades (GONÇALVES, Carlos Roberto. Direito civil brasileiroParte geral. 10. ed. São Paulo: Saraiva, 2012. p. 334. v. 1). Advoga-se que as declarações prévias não sejam feitas na modalidade receptícia, pois não possuem um destinatário especial e dependeriam da anuência dos médicos e demais profissionais de saúde, o que parece muito difícil de acontecer tendo em vista o modelo de saúde pública brasileiro em que os médicos trabalham em sistema de rodízio de plantão, alternando no atendimento emergencial e ambulatorial. Muito embora esses profissionais possam deixar declarada sua objeção de consciência, eles devem envidar esforços para o cumprimento das diretrizes/ declaração, encaminhando o paciente para que alguém a cumpra. Contudo, para a eficácia do contrato de mandato vindouro deve haver a ciência do mandatário e de sua manifestação, pois o encargo de se tomar conta de alguém, que pode permanecer enfermo por tempo imprevisível, precisa ser aceito.

57 A declaração de vontade precisa ter por escopo a finalidade negocial, ou seja, visando à produção dos efeitos. O negócio jurídico tem como pano de fundo a autonomia privada em que a pessoa declara sua escolha (GONÇALVES, Carlos Roberto. Direito civil brasileiro - Parte geral. 10. ed. São Paulo: Saraiva, 2012. p. 338. v. 1).

58 A idoneidade do objeto recai sobre a ideia de fungibilidade, isto é, deve apresentar os requisitos necessários e legais para a sua concretude. As diretivas antecipadas lidam com a saúde do declarante, coisa infungivel, sendo essa a sua qualidade e requisito (GONÇALVES, Carlos Roberto. Direito civil brasileiro - Parte geral. 10. ed. São Paulo: Saraiva, 2012. p. 338. v. 1). 
A vontade precisa ser manifestada e não apenas restrita ao mundo interno. A declaração é o mecanismo que externa a vontade, revelando-a. A vontade pode acontecer de forma expressa através da fala ou escrita, de mímica, de sinais e de gestos (caso dos surdos-mudos). A vontade tácita se revela pelo comportamento do indivíduo e, na hipótese de contratos, só é tácita se a lei não demandar a forma expressa. Na presumida, impera o mandamento legal. ${ }^{59}$

Um dos requisitos de validade do negócio jurídico é a manifestação espontânea e livre da vontade. Podem ocorrer defeitos na formação da vontade e na manifestação dela, que torna o negócio jurídico anulável. Esses são os vícios de consentimento: erro, dolo, coação, estado de perigo, lesão. ${ }^{60}$ Eles afetam a vontade e refletem na validade do negócio jurídico, exceto a coação física e a simulação, que geram nulidade absoluta. Os vícios de consentimento estão na categoria das nulidades relativas, assim como os negócios realizados por relativamente incapazes, como os maiores de 16 e menores de 18 anos de idade, os ébrios habituais, os pródigos e os viciados em tóxicos, bem como os indivíduos que não puderem expressar sua vontade por causa transitória ou permanente, sem a devida assistência. ${ }^{61}$ Nesta última hipótese entrariam os comatosos e os pacientes em estado neurovegetativo persistente.

Desta feita, diante da ausência de qualquer consentimento, inexistindo manifestação de vontade, há a inexistência do negócio jurídico. Havendo o consentimento, mas maculado de vício de consentimento, o negócio é anulável, e o consentimento expresso por absolutamente incapaz, tem-se a nulidade do negócio, apesar de existir. ${ }^{62}$

59 GONÇALVES, Carlos Roberto. Direito civil brasileiro - Parte geral. 10. ed. São Paulo: Saraiva, 2012. p. 333-334. v. 1.

60 Sendo substancial o erro, o negócio é anulável (art. 138, CC). 0 erro é um equívoco fático, uma noção errada sobre algo ou pessoa, mas que pode ser notado por pessoa de diligência normal. Desde a adoção do princípio da confiança com apreço pela eticidade, não mais se busca descobrir se o erro é justificável, de acordo com o Enunciado № 12 do Conselho de Justiça Federal; o dolo (art. 145, CC) é outra causa de anulação, assim como o dolo do representante legal; na coação, é importante o alerta do art. 152 do CC em que o juiz precisa ficar atento para a condição, a saúde, a idade, o temperamento e o sexo do paciente. A coação moral, como a psicológica, torna o negócio jurídico viciado; o estado de perigo é quando a pessoa ou alguém de sua família ou afeto está em perigo e realiza negócio atraindo, para si, obrigação excessivamente onerosa, com alguém que tem conhecimento dessa condição (médico que cobra um valor excessivamente maior do que o real para realizar cirurgia em paciente com iminência de perder a via). A lesão ocorre quando há a imediata necessidade ou inexperiência (elemento subjetivo) somando-se à onerosidade excessiva (elemento objetivo), resultando em uma prestação excessivamente desproporcional (contrato de compra e venda de imóvel) (TARTUCE, Flávio. Manual de direito civil: volume único. 6. ed. rev., atual. e ampl. Rio de Janeiro: Forense; São Paulo: Método, 2015. p. 191-202).

61 BRASIL. Código Civil: Lei 10.406, de 10 de janeiro de 2002. In: CURIA, Luiz Roberto; CÉSPEDES, Lívia; ROCHA, Fabiana Dias (Colab.). Vade Mecum. 21. ed. atual. e ampl. São Paulo: Saraiva, 2016. p. 876.

62 GONÇALVES, Carlos Roberto. Direito civil brasileiro - Parte geral. 10. ed. São Paulo: Saraiva, 2012. p. 455. v. 1. 
No campo das nulidades absolutas, existe ofensa às normas de ordem pública, afetando o plano da validade, consubstanciado no inc. I do art. 166 do Código Civil, se o negócio for celebrado por absolutamente incapaz que não representado, nos termos do art. 3o do Código Civil, como é o caso dos menores de 16 anos sem representação dos pais, de tutor, ou curador. Desde a entrada em vigor do Estatuto da Pessoa com Deficiência, contudo, a pessoa com deficiência mental e o enfermo figuram entre os plenamente capazes, restando incapazes absolutamente apenas os menores de 16 anos de idade. 0 interesse do legislador foi o de inserir os que não possuem discernimento para a prática da vida civil e aqueles que possuem o discernimento reduzido. ${ }^{63} 64$

Segundo o inc. II do art. 166, a ilicitude do objeto gera a nulidade absoluta do negócio jurídico pela infração do ordenamento jurídico e das normas éticas, assim como a impossibilidade de realização e execução física (como curar doença incurável) ou jurídica do objeto, ${ }^{65}$ e a indeterminação (podendo ser indeterminável) deste. Assim, há a impossibilidade jurídica das declarações prévias, e das diretivas antecipadas, se o seu objeto adotar a prática da eutanásia, considerada homicídio pelo art. 121 do Código Penal, e suicídio assistido, ajustado ao art. 122 da mesma norma penal ${ }^{66}$ e art. 15 do Código Civil, e ilícito, já que vedados, também, pelo art. 41 do Código de Ética Médica de 2009. ${ }^{67}$ Quanto ao enquadramento da ortotanásia, embora não esteja prevista de forma expressa nem mesmo pela normativa ética médica, pode-se buscar guarida no inc. III do art. 1ํ da Constituição Federal de $1988,{ }^{68}$ que trata do princípio da dignidade da pessoa humana, além

63 BRASIL. Código Civil: Lei 10.406, de 10 de janeiro de 2002. In: CURIA, Luiz Roberto; CÉSPEDES, Lívia; ROCHA, Fabiana Dias (Colab.). Vade Mecum. 21. ed. atual. e ampl. São Paulo: Saraiva, 2016. p. 875-6 e 937; e BRASIL. Estatuto da Pessoa com Deficiência: Lei Brasileira de Inclusão n. 13.146, de 06 de julho de 2015. In: CURIA, Luiz Roberto; CÉSPEDES, Lívia; ROCHA, Fabiana Dias (Colab.). Vade Mecum. 21. ed. atual. e ampl. São Paulo: Saraiva, 2016. p. 5.028.

64 Enquanto a declaração de vontade constitui requisito para a existência do negócio jurídico, a capacidade é elemento de validade.

65 GONÇALVES, Carlos Roberto. Direito civil brasileiro - Parte geral. 10. ed. São Paulo: Saraiva, 2012. p. 342-343. v. 1. O autor preleciona que a impossibilidade jurídica do objeto é afeta ao que é proibido pelo ordenamento jurídico. Já a ilicitude possui maior abrangência envolvendo questões morais, relativas aos bons costumes e principiológicas.

66 BRASIL. Decreto-lei n. 3.914 de 09 de dezembro de 1941. In: CURIA, Luiz Roberto; CÉSPEDES, Lívia; ROCHA, Fabiana Dias (Colab.). Vade Mecum. 21. ed. atual. e ampl. São Paulo: Saraiva, 2016. p. 2.5042.508.

67 CFM - Conselho Federal de Medicina. Código de Ética Médica. Resolução do CFM n. 1.931/2009. In: FRANÇA, Genival Veloso. Direito médico. 11. ed. rev., atual. e ampl. Rio de Janeiro: Forense, 2013. p. 584.

68 BRASIL. Constituição da República Federativa do Brasil. In: CURIA, Luiz Roberto; CÉSPEDES, Lívia; ROCHA, Fabiana Dias (Colab.). Vade Mecum. 21. ed. atual. e ampl. São Paulo: Saraiva, 2016. p. 167. 
das resoluções nos 1.805/2006 ${ }^{69}$ e 1.995/2012, ${ }^{70}$ e o parágrafo único do art. 41 do Código de Ética Médica, todos exarados pelo Conselho Federal de Medicina.

A ausência de norma proibitiva permite aos particulares realizarem atos jurídicos, desde que não afete o ordenamento jurídico. As declarações prévias, conhecidas erroneamente por testamento vital, já são uma realidade existente em vários países. O fundamento mais plausível é que pode evitar conflitos entre os familiares, já que o interesse do doente estaria preservado mesmo diante da inexistência de legislação em que pese ser importante a regulamentação específica. A inexistência legal permite a utilização da forma livre conforme o art. 107 do Código Civil, embora se prefira que o documento seja formalizado na presença de tabelião e que siga, analogicamente, os requisitos formais do testamento. O obstáculo da ilicitude dos arts. 104, II, e 106, II, do Código Civil, fica restrito à prática da eutanásia e não da ortotanásia. Neste ponto, ainda que se tenha a vida como um bem supremo, em situações extremas como no caso dos pacientes terminais impera o dever ético de cuidar dos pacientes paliativamente. ${ }^{71}$

A forma não precisa ser revestida de solenidade, podendo ser realizada por instrumento público ou particular, na presença de testemunhas, embora a escrituração pública garanta maior segurança ao paciente, aos familiares e tutores, aos médicos e demais profissionais e instituições envolvidos no atendimento. Isso porque a prestação dos serviços de saúde está cada vez mais socializada e

69 Resolução no 1.805/2006 permitiu ao médico restringir ou suspender tratamentos que prolonguem a sobrevida de pacientes terminais com enfermidade grave e incurável, sem, entretanto, deixar de prestar os cuidados necessários para minimizar a dor e o sofrimento, respeitando-se a vontade do paciente ou de seu representante legal (art. $1^{\circ}$ ). Ao paciente deve ser disponibilizada toda a assistência abrangendo o bem-estar físico, social, psíquico e espiritual, devendo receber alta hospitalar caso assim o prefira. A resolução ampara o direito de informação do paciente ou do representante legal a respeito das terapias utilizadas de acordo com a doença (art. 1ํ, $1^{\circ} \stackrel{\circ}{)}$ ), devendo, a declaração do paciente, ser fundamentada e constar no prontuário (art. 1ํㅡ, $\left.\S^{2}{ }^{\circ}\right)($ CFM - Conselho Federal de Medicina. Resolução n. 1.805/2006. Disponível em: <http://www.portalmedico.org.br/resolucoes/cfm/2007/111_2007.htm>. Acesso em: 6 jul. 2015).

70 Por meio da Resolução no 1.995/2012, o Conselho Federal de Medicina dispõe sobre a necessidade de valorizar a autonomia do paciente em sua interface com as diretivas, ante a utilização de instrumentos tecnológicos limitados em prolongar a vida e o sofrimento de pacientes terminais, a partir de imódicas intervenções, "medidas desproporcionais", sem produzir quaisquer benefícios ou perspectivas de melhora à saúde. Diferentemente da Resolução no 1.805/2006, a de 2012 sugere o alargamento de abrangência das diretivas, não se limitando a pacientes terminais (CFM - Conselho Federal de Medicina. Resolução $n$. 1.995/2012. Dispõe sobre as diretivas antecipadas de vontade dos pacientes. Disponível em: <http:// www.portalmedico.org.br/resolucoes/CFM/2012/1995_2012.pdf>. Acesso em: 6 jul. 2015).

71 GODINHO, Adriano Marteleto. Diretivas antecipadas de vontade: testamento vital, mandato duradouro e sua admissibilidade no ordenamento jurídico brasileiro. Instituto de Direito Brasileiro, Lisboa, ano 1, n. 2, p. $945-78,2012$. p. 957-963. 
coletiva, envolvendo setores públicos e privados. Entretanto, a forma prevista no art. 104 da Norma Civil ${ }^{72}$ não pode ser defesa em lei. ${ }^{73}$

Para que produza efeitos, as declarações prévias dependem da condição da incapacidade permanente e irreversível de doença futura do interessado, que é um evento incerto ${ }^{74}$ conforme o art. 121 do Código Civil, e, seguindo a linha da ética médica brasileira, o indivíduo deve se encontrar em fase terminal da doença (Resolução no 1.805), sob pena de ofender a eticidade, embora a Resolução no 1.995/2012 tenha alargado essa possibilidade, sem esclarecer a profundidade

72 BRASIL. Código Civil: Lei 10.406, de 10 de janeiro de 2002. In: CURIA, Luiz Roberto; CÉSPEDES, Lívia; ROCHA, Fabiana Dias (Colab.). Vade Mecum. 21. ed. atual. e ampl. São Paulo: Saraiva, 2016. p. 921.

73 A minuta da escritura pública das diretivas antecipadas de vontade utilizada pelos cartórios do estado de São Paulo é constituída pela qualificação das partes; nomeação e qualificação de procuradores; fundamentos constitucionais e legais (dignidade da pessoa humana e resoluções do Conselho Federal de Medicina); objeto (uma declaração de vontade sobre os direitos do corpo, da personalidade e da administração do patrimônio do requerente diante de possível moléstia grave ou acidente que venham a impedir a sua manifestação de vontade. Neste espaço, o declarante orienta os médicos no tocante às preferências sobre procedimentos terapêuticos e diagnósticos, e, ainda, na condição clínica irreversível e terminal, ele pode rechaçar a execução de procedimentos diagnósticos e terapêuticos desnecessários e adotar cuidados paliativos apropriados, de modo a evitar a dor e o sofrimento físico, espiritual e moral); autorização e consentimento do declarante para: a) em caso de coma irreversível e esgotadas as possibilidades de vida sem o uso de aparelhos, o declarante autoriza e deseja o desligamento do suporte vital (ou a sua manutenção), b) gravidez, proceda-se de maneira a salvar o feto e, nascendo vivo ou morto, sejam aplicadas essas diretrizes. O declarante pode (ou não) autorizar o uso do material genético para tratamento de seus familiares, a utilização do sêmen para fecundar o óvulo de sua esposa, podendo a gestação ser feita pela esposa ou familiar, dentro de 2 anos; diagnóstico médico realizado, obedecendo aos ditames da Lei no 9.434/97, art. 3o, sobre os requisitos para a constatação da morte encefálica. 0 declarante também pode deliberar sobre um futuro estado vegetativo persistente durante o qual não desejaria: ter estendida sua sobrevida mediante aparelhos, ou que seja submetido a procedimentos cirúrgicos que o privem de viver normalmente e que apenas Ihe prolonguem a vida, seja amputado algum membro, que a sua vida seja estendida mediante a utilização de equipamento, por exemplo, bolsas de colostomia (auxílio na eliminação de fezes), seja mantido vivo por período superior a 6 meses se estiver inconsciente e, havendo permissão legislativa, seja realizada a prática da eutanásia, ou a transferência para país onde permitida; o declarante elege um representante para tomar conta do seu tratamento médico se estiver incapaz de se expressar, seguindo o determinado nas diretrizes e, havendo omissão, agirá segundo os seus critérios; representação para atuar junto a médicos, clínicas, hospitais e necrotérios, no sentido de obter prontuário médico do paciente, cópias de documentos ou informações a respeito do tratamento de saúde e causas da morte, de acordo com o Parecer do Conselho Federal de Saúde nº 6/2010 (trata do sigilo na liberação de prontuário médico aos familiares cuja liberação só pode ocorrer mediante autorização judicial ou requisição do CFM ou CRM), autorizar autopsia ou necropsia, transporte dos restos mortais, e liberação do corpo de hospitais ou necrotérios para funeral; poderes de administração patrimonial; autorização de acesso à residência do declarante; o termo inicial e final do mandato, a saber, respectivamente, da incapacidade do declarante para exercer direitos ou atos da vida, e, com a morte, interdição legal, retorno do declarante com discernimento para os atos da vida civil; doação de órgãos; exéquias (cremação do corpo) (FERREIRA, Paulo Roberto Gaiger. Nova minuta (versão 2012): Escritura Pública de Diretivas Antecipadas de Vontade e Outras Disposições, 2012. 26을 Tabelionato de notas 12 nov. 2012. Disponivel em: <https://www.26notas.com.br/blog/?p=6536>. Acesso em: 7 abr. 2016).

74 A incerteza abrange não somente a incapacidade, mas também o tempo, diferentemente da morte que é um evento certo e indeterminado. 
das diretivas, deixando esse papel para o legislador. ${ }^{75} \mathrm{~A}$ condição, nesse caso, não é elemento acidental e acessório ao negócio jurídico, mas faz parte dele. É uma autolimitação da vontade.

O mandato vindouro também não está regulamentado, contudo inexiste legislação proibitiva no Código Civil, como pode ser visto nos arts. 115 a 120, que cuidam da representação, nem nos arts. 653 a 692, que tratam do mandato. Os fundamentos para as declarações prévias também cabem ao mandato vindouro, entre eles, especialmente, o consentimento livre e esclarecido e a capacidade do mandante. ${ }^{76}$

O mandato ocorre quando alguém transfere poderes a outrem, para que este, em nome daquele, pratique atos ou administre interesses, perfazendo um “negócio jurídico de representação”. É um contrato bilateral, gratuito, consensual, comutativo - uma vez que as partes conhecem suas obrigações -, informal, não solene, personalíssimo, baseado na confiança, na fidúcia que o mandante tem pelo mandatário, e convencionado entre as partes. ${ }^{77}$

No contrato de mandato, o mandatário ou outorgado aceita a obrigação de realizar condutas, obrigação de fazer, visando à defesa dos interesses do mandante outorgante. Consiste em um contrato de serviço em que o mandatário pratica condutas e administra os interesses do mandante através da prestação de serviços. 0 documento de mandato pode ser feito de forma escrita, oral ou tácita, esta quando o mandatário pratica ato executório que represente sua aceitação. ${ }^{78}$ A posição defendida neste artigo por estas articulistas, entretanto, é de que o mandato vindouro deva ser realizado na forma escrita e, na sua impossibilidade, a rogo, nesta hipótese na presença de duas testemunhas.

Na procuração, o mandatário possui a função de procurador/representante do mandante. Quando inexiste previsão legal de representação, o fundamento se baseia na convenção entre as partes, na relação de confiança. A consensualidade advém da consonância de vontades das partes e os poderes são limitados ao alcance da representação, podendo haver pluralidade de representantes. ${ }^{79}$

As obrigações do mandatário consistem em cumprir diligentemente a obrigação para a qual se obrigou, sob pena de indenizar o mandante, não podendo

75 BRASIL. Código Civil: Lei 10.406, de 10 de janeiro de 2002. São Paulo: Revista dos Tribunais, 2002. p. 925.

76 GODINHO, Adriano Marteleto. Diretivas antecipadas de vontade: testamento vital, mandato duradouro e sua admissibilidade no ordenamento jurídico brasileiro. Instituto de Direito Brasileiro, Lisboa, ano 1, n. 2, p. 945-78, 2012. p. 968-969.

77 TARTUCE, Flávio. Direito civil 3: teoria geral dos contratos e contratos em espécie. 7. ed. rev. e atual. São Paulo: Método, 2012. p. 489-493.

78 COELHO, Paulo Ulhoa. Curso de direito civil: contratos. 5. ed. São Paulo: Saraiva, 2012. p. 645-651.

79 COELHO, Paulo UIhoa. Curso de direito civil: contratos. 5. ed. São Paulo: Saraiva, 2012. p. 645-651. 
transpor os limites do mandato; ele deve obedecer às instruções estabelecidas pelo mandante para a execução do mandato, não exorbitando os poderes de mandatário de modo a prejudicar o mandante. Sem embargo, se o mandatário for maior de dezesseis e menor de dezoito anos de idade, não tem a obrigação de indenizar o mandante pelo dever diligente, assim como aos pais deste ou tutor, mesmo que culposamente realizado. ${ }^{80} 0$ substabelecimento pode ocorrer desde que autorizado pelo mandante. ${ }^{81}$

A revogação é uma declaração feita unilateralmente pelo mandante intencionando suprimir os poderes do mandatário. Ela é sempre possível mesmo que a outorga seja feita incluindo cláusula de irrevogabilidade. Ademais, ela consiste em negócio jurídico receptício, ou seja, seus efeitos só se aperfeiçoam quando o mandatário toma conhecimento da declaração (art. 683, CC). A designação de novo representante para o mesmo negócio equivale à revogação do contrato de mandato (art. 687). o mandatário pode renunciar ao mandato declarando sua intenção unilateralmente, contanto que o mandante tome conhecimento do ato. Essa é uma hipótese possível desde que o mandatário não renuncie de forma injusta, causando prejuízos ao mandante, como exemplo, no caso de inexistir tempo suficiente para promover a substituição. É considerada justa a renúncia se os poderes outorgados oneram excessivamente o mandatário e ele não possui o poder do substabelecimento (art. 688). Os atos de revogação e de renúncia precisam ser expressos. ${ }^{82}$

A morte do mandante ou do mandatário é forma de extinção do contrato. ${ }^{83}$ Embora a interdição do mandante também seja considerada causa de extinção da outorga, no caso do mandato vindouro/duradouro, segue-se a linha de que a interdição do mandante não importa a extinção do mandato, somente a interdição do mandatário poderia interromper o mandato por se tratar de ato personalíssimo. No mandato vindouro, por ser um negócio jurídico bilateral, verificam-se as vontades tanto do outorgante/mandante, como do outorgado/mandatário. Frise-se que o mandato vindouro pode ser realizado independentemente das declarações prévias, não se limitando à situação de terminalidade (fim de vida). Por conseguinte, as diretivas não se restringem a essa condição.

Retomando o assunto da capacidade para a autodeterminação de disposições de vontade, a aquisição da maturidade não é um evento repentino, acontecendo paulatina e progressivamente. Pelo Código Civil de 2002, nos arts. 3ํㅗ 4ํㅡㄹ 5으, o desenvolvimento infantojuvenil parte dos absolutamente incapazes para os atos

COELHO, Paulo Ulhoa. Curso de direito civil: contratos. 5. ed. São Paulo: Saraiva, 2012. p. 652-658.

81 COELHO, Paulo Ulhoa. Curso de direito civil: contratos. 5. ed. São Paulo: Saraiva, 2012. p. 665.

82 COELHO, Paulo Ulhoa. Curso de direito civil: contratos. 5. ed. São Paulo: Saraiva, 2012. p. 674-677.

83 COELHO, Paulo Ulhoa. Curso de direito civil: contratos. 5. ed. São Paulo: Saraiva, 2012. p. 677. 
da vida civil, os menores de 16 anos de idade, passando pelos relativamente incapazes entre 16 e 18 anos de idade, até alcançar a maioridade aos 18 anos, quando a pessoa é considerada pronta para exercer todos os atos da vida civil. Antes da Lei no 13.146/2015, do Estatuto da Pessoa com Deficiência, o art. 3o incluía em seu rol de absolutamente incapazes os deficientes mentais e os enfermos que não tivessem o necessário discernimento para a prática dos atos da vida civil, e, no art. 4을 , entre os relativamente incapazes, ao lado dos ébrios habituais e dos viciados em tóxicos, as pessoas com deficiência mental, com discernimento reduzido, e os excepcionais sem desenvolvimento mental completo. ${ }^{84}$

De acordo com o Código, os absolutamente incapazes são aqueles que não possuem qualquer discernimento, precisando ser representados sem fazer parte do ato de forma pessoal. Depois dos 16 anos, são enquadrados entre os relativamente incapazes em vista da redução do seu discernimento, praticando atos assistidos por representante legal. A capacidade de toda pessoa natural é a regra, logo as únicas exceções são as discriminadas taxativamente nos arts. 3ํㅡㄴ e 4ํ. O Código Civil, historicamente, protege as pessoas com deficiência, tanto é que os incapazes são curatelados, pois a interdição reconhece a incapacidade em virtude de doença ou deficiência, além das hipóteses de prodigalidade e vício, como descreve o art. 1.767 do Código Civil. O papel do curador é de representar ou assistir o curatelado. ${ }^{85}$

A partir do Estatuto da Pessoa com Deficiência, contudo, a pessoa com deficiência mental e o enfermo são compreendidos entre os plenamente capazes, aferindo a absoluta incapacidade tão somente aos menores de 16 anos de idade. O entendimento do legislador foi o de incluir os que não possuem discernimento para a prática da vida civil e aqueles que possuem o discernimento reduzido. ${ }^{86}$ Os efeitos resultantes dessa nova norma afetam diretamente os interditados, que passam a ser capazes, dispensando-se a necessidade de levantar a interdição. Assim, o art. 6o do Estatuto inclui como capazes os enfermos, os deficientes mentais e os excepcionais. O grande problema colocado está em relação às pessoas que não são capazes de manifestar sua vontade devido à deficiência grave e profunda, mas que vinham sendo representadas em sua maioria pelos

84 BRASIL. Código Civil: Lei 10.406, de 10 de janeiro de 2002. São Paulo: Revista dos Tribunais, 2002. p. 875-876; 937; e BRASIL. Estatuto da Pessoa com Deficiência: Lei Brasileira de Inclusão n. 13.146, de 06 de julho de 2015. In: CURIA, Luiz Roberto; CÉSPEDES, Lívia; ROCHA, Fabiana Dias (Colab.). Vade Mecum. 21. ed. atual. e ampl. São Paulo: Saraiva, 2016. p. 5.028.

85 SIMÃO, José Fernando. Estatuto da pessoa com deficiência causa perplexidade (parte 1). Revista Consultor Jurídico, p. 1-6, ago. 2015. p. 1-2.

86 SIMÃO, José Fernando. Estatuto da pessoa com deficiência causa perplexidade (parte 1). Revista Consultor Jurídico, p. 1-6, ago. 2015. p. 1-2. 
pais, tornando-se, abruptamente, capazes, não sendo mais representadas nem assistidas, a despeito de não conseguirem expressar sua vontade. Ademais, elas poderão realizar negócios jurídicos como celebração de contratos que, ainda que desvantajosos, terão validade porque firmados por pessoas capazes, sujeitos apenas à constatação de vícios do consentimento. ${ }^{87}$

0 art. 6ำ do Estatuto preceitua que a capacidade civil da pessoa não é afetada pela deficiência, até mesmo com relação a casamento e constituição de união estável; a exercício dos direitos sexuais e reprodutivos; à decisão sobre o seu planejamento familiar, inclusive o número de filhos; além de ao exercício do direito à tutela, à guarda, à curatela e à adoção, quer seja na posição de adotante ou adotando. $\mathrm{O}$ art. 12 determina imprescindibilidade do recolhimento do consentimento prévio, livre e esclarecido, caso a pessoa com deficiência necessite de algum procedimento, tratamento, hospitalização ou se submeta à pesquisa científica. o parágrafo único assegura a maior participação possível ao deficiente curatelado no processo de coleta da manifestação do consentimento. Haverá a dispensa do consentimento se a pessoa com deficiência estiver em risco de morte e em situação emergencial, respeitado os seus interesses e as normativas legais. ${ }^{88}$

Está-se com o Professor José Fernando Simão quanto ao problema da manifestação das pessoas com deficiência grave que não conseguem manifestar sua vontade e decidir sobre tratamento, hospitalização ficando difícil ao médico, inclusive, coletar o consentimento do paciente prévio, livre e esclarecido. É louvável, todavia, o exposto no parágrafo único do art. 12, sobre a participação da pessoa com deficiência que se encontre sob curatela ser a mais completa possível.

O Conselho Federal de Medicina regulamentou na Resolução no 1.995/2012, no art. $2^{\circ}, \delta \S 1^{\circ}$ e $2^{\circ}$, na qual, quanto aos pacientes incapazes de se comunicar, ou que não consigam manifestar livre e independentemente suas vontades, fica assegurado que o médico considerará as diretivas antecipadas de vontade no momento de decidir sobre cuidados e tratamentos, acatando, inclusive as informações relatadas pelo representante do paciente, caso este tenha designado previamente, salvo se as diretivas antecipadas de vontade não estiverem de acordo com as determinações prescritas no Código de Ética Médica. A resolução,

87 SIMÃO, José Fernando. Estatuto da pessoa com deficiência causa perplexidade (parte 1). Revista Consultor Jurídico, p. 1-6, ago. 2015. p. 2-4.

88 BRASIL. Estatuto da Pessoa com Deficiência: Lei Brasileira de Inclusão n. 13.146, de 06 de julho de 2015. In: CURIA, Luiz Roberto; CÉSPEDES, Lívia; ROCHA, Fabiana Dias (Colab.). Vade Mecum. 21. ed. atual. e ampl. São Paulo: Saraiva, 2016. p. 5.028; 5.030. 
destarte, não exige obrigatoriamente que os desejos do representante sejam atendidos, mas que sejam levados em consideração.

O parágrafo único do art. 41 do Código de Ética Médica, em vigor desde abril de 2010, disciplina que a vontade do paciente será tomada em consideração e, não sendo possível obtê-la, far-se-á através do representante legal. Nesse mesmo capítulo, o Conselho Federal de Medicina proíbe as terapias inúteis e obstinadas (distanásia) e orienta os médicos em favor dos cuidados paliativos em face de paciente terminal ou acometido de doença incurável. Não obstante, o médico poderá não atender às diretrizes do paciente caso elas sejam incompatíveis com o Código de Ética, ou seja, o limite para as diretivas antecipadas de vontade está na hipótese de atendimento de pacientes que possam ser salvos, prevalecendo, neste aspecto, a autonomia do médico. ${ }^{89}$

Por ora, a elaboração das diretivas está atrelada à condição da maioridade civil (dezoito anos) desde que com capacidade plena (distinguindo-se da regra do art. 1.860 do Código Civil que regulamenta o testamento propriamente dito, possibilitando que maiores de 16 anos possam exercer esse direito). Elas são atos personalíssimos (incluso o testamento vital), assim como o testamento e o consentimento do paciente, de modo que uma eventual incapacidade superveniente (art. 1.861, CC) não invalida aquela manifestada anteriormente, e só têm validade se formalizada por manifestação livre e espontânea não maculada por vícios de consentimento. Elas são revogáveis, adotando-se analogicamente os ditames civilistas para o testamento (art. 1.858 do Código Civil). ${ }^{90}$

As diretivas antecipadas de vontade são uma forma de garantir que o paciente terminal tenha em resguardo suas convicções morais e religiosas, firmando-se como uma demonstração em concreto do princípio constitucional da dignidade da pessoa humana. Wilson Steinmetz ${ }^{91}$ afirma que a dignidade da pessoa humana é um fundamento para a Constituição da República Federativa do Brasil (art. 1ํㅡ, III), entendido como um princípio constitucional fundamental autônomo. Em vista disso, é projetado sobre as demais normas constitucionais e infraconstitucionais com as quais mantém um vínculo sistemático e teleológico (interpretativo) e propaga, de forma autônoma, normas de obrigação e de proibição aos casos concretos, incidindo eficazmente nestes.

89 CFM - Conselho Federal de Medicina. Código de Ética Médica. Resolução do CFM n. 1.931/2009. In: FRANÇA, Genival Veloso. Direito médico. 11. ed. rev., atual. e ampl. Rio de Janeiro: Forense, 2013. p. 584 e CARTÓRIO hoje: serviços de cartório na internet. Revista ANOREG/SP, n. 3, p. 24-29, dez. 2012.

90 GODINHO, Adriano Marteleto. Diretivas antecipadas de vontade: testamento vital, mandato duradouro e sua admissibilidade no ordenamento jurídico brasileiro. Instituto de Direito Brasileiro, Lisboa, ano 1, n. 2, p. 945-78, 2012. p. 962.

91 STEINMETZ, Wilson. A vinculação dos particulares a direitos fundamentais. São Paulo: Malheiros, 2004. p. 113. 
O processo de morrer de forma digna é um direito subjetivo do paciente que pode ser concretizado mediante o registro dos seus desejos sob a forma de diretivas e que atrai a aplicabilidade direta da dignidade como um direito fundamental na relação médico-paciente e como um limite às práticas médicas. A medicina, imbuída de espírito de preservação da vida, não pode mais ser usada de forma obstinada pelo médico, no sentido kantiano de não transformar a pessoa do paciente como um meio. Por outro lado, é imperiosa a necessidade de regulamentação legislativa como forma de proteger o profissional da saúde frente a futuros processos de responsabilização.

Em termos médicos, o entendimento de dignidade da pessoa humana que mais se aproxima é o conceito de Ingo Wolfgang Sarlet, no sentido de que seja um adjetivo humano intrínseco, porém passível de certa relativização, preservando-se, contudo, o seu núcleo essencial. Discorda-se no ponto em que Sarlet intercede pela necessidade de "tolerância" nas comunidades multiculturais, preferindo-se o instituto da alteridade preconizada por Emmanuel Lévinas. Ademais, são válidas as palavras de Jonas afirmando que a morte é detentora da própria dignidade, sendo um direito humano deixar seguir o seu curso normal.

A dignidade da pessoa humana, na relação médico-paciente, envolve a mitigação da dor e do sofrimento, o respeito pelo paciente e pela sua autonomia na tomada de decisão sobre onde prefere morrer, a adequada informação sobre sua enfermidade e riscos resultantes das intervenções, acesso a terapias e tratamentos que possam atenuar a sua angústia, oferecer a possibilidade de renunciar ou suspender técnicas terapêuticas, não desamparar o paciente, respeitar as suas crenças. ${ }^{92}$

Ressalte-se o papel da teoria da eficácia imediata como grande motivadora da eficácia direta dos direitos fundamentais nas relações entre particulares, in casu, entre o paciente e o médico, da dignidade da pessoa humana materializada na forma de diretivas antecipadas de vontade, como limite à autonomia médica no tocante a práticas terapêuticas de postergação da morte contrárias à vontade do paciente.

92 RECKZIEGEL, Janaína; CONINCK, Beatriz Diana Bauermann. Entre a vida e a morte: revisitando a morte digna em pacientes terminais. In: MARCO; Christian Magnus de; KRAVETZ, Rafaella Zanatta Caon. Diálogos sobre direito e justiça: coletânea de artigos. Joaçaba: Ed. Unoesc, 2015. p. 23. v. 1. 


\section{Considerações finais}

O escopo deste artigo centrou-se na averiguação das diretivas antecipadas de vontade como condições ou pressupostos de manifestação do interessado aferíveis e válidos, em concreto, em sua pretensão de exercer o direito constitucional de morrer com dignidade, adotando como marco teórico a teoria da eficácia imediata, e a dignidade como limite a práticas médico-terapêuticas. Embasou-se o estudo nos enfoques filosóficos, bioéticos, médicos e jurídicos da dignidade da pessoa humana no primeiro item; o segundo tópico explorou a teoria da eficácia imediata; e o terceiro ponto respondeu se as diretivas antecipadas de vontade são instrumentos concretos de aferição da dignidade da pessoa humana em pacientes terminais, sob a ótica da teoria da eficácia imediata, de modo que a dignidade seja tomada como um fundamento útil, abstrato e concreto, para a realização das disposições de vontade do paciente.

Verificou-se que as diretivas antecipadas de vontade estão estreitamente atreladas às situações existenciais e, por conseguinte, atraem a aplicabilidade direta da dignidade humana nos moldes kantianos da não coisificação do paciente como destinatário das técnicas biotecnológicas. Destacou-se o conceito trazido por Ingo Wolfgang Sarlet, de importante relativização do conceito em razão das influências históricas e culturais. No caso dos pacientes terminais, a acepção de Jonas sobre a dignidade consistente em permitir o transcorrer natural da morte como critério para a dignidade humana ajusta-se à defendida teoria da eficácia imediata, não pelo viés da autonomia do paciente, mas da dignidade que lhe é intrínseca. Aponta-se, também, a substituição da referência de Sarlet sobre tolerância para a alteridade de Lévinas, especialmente dentro da ética médica.

A teoria da eficácia imediata pareceu constituir a melhor contribuição no sentido da concretização da dignidade no processo de falecer, tendo como veículo as diretivas antecipadas de vontade, vez que defende a aplicabilidade imediata da dignidade como barreira para a prática médico-terapêutica, restando aos médicos contribuir no sentido da atenuação da dor e do sofrimento, do respeito pelo paciente e pela sua autonomia na tomada de decisão sobre onde prefere morrer, da adequada informação sobre sua enfermidade e riscos resultantes das intervenções, do acesso a terapias e tratamentos que possam atenuar a sua angústia, da possibilidade de renúncia ou suspensão de técnicas terapêuticas, do não desamparo do paciente, do respeito pelas convicções particulares dos pacientes - sendo essa a resposta que se dirige a Ruth Macklin, da utilidade da dignidade humana. 


\title{
Advance directives of will as a condition to measure in concrete dying with dignity in the light of the immediate efficacy theory
}

\begin{abstract}
This article aims to investigate whether the Advance Directives of Will are conditions or assumptions of manifestation of the concerned person able to make gaugeable and valid in concrete his intention to exercise the constitutional right to dignified death, taking as theoretical framework the Immediate Efficacy Theory. Therefore, human person's dignity will be studied under philosophical, medical ethics and juridical focus, along the first topic; the second item will approach about the Immediate Efficacy Theory; and the third point will treat about Advance Directives of Will and the possibility of this resource be a measurement requirement in concrete of the human dignity of endof-life patients according to the Immediate Efficacy Theory. Deductive method of qualitative approach will be applied, starting from general notions about human dignity, passing by the investigation of the Immediate Efficacy Theory and Advance Directives, in order to be applied to end-of-life situations. The research will approach qualitatively national and international researches. It is concluded that Immediate Efficacy Theory enables human dignity to take effect before the inevitable death of terminal patients by performing the Advance Directives, thus proving their practical utility.
\end{abstract}

Keywords: Human person's dignity. Advance directives of will. Fundamental rights Immediate efficacy theory. End-of-life patients.

Summary: 1 Introduction - $\mathbf{2}$ Human person's dignity through the prism of philosophy, medical ethics and legal - 3 Fundamental rights Immediate Efficacy Theory - 4 Advance directives of will, human dignity and the Immediate Efficacy Theory - 5 Final considerations - References

\section{Referências}

ALEXY, Robert. Teoria dos direitos fundamentais. Tradução de Virgílio Afonso da Silva. São Paulo: Malheiros, 2008.

ARISTÓTELES. Ética a Nicômaco. Seleção de textos de José Américo Motta Pessanha. 4. ed. São Paulo: Nova Cultural, 1991. v. 2. Coleção Os Pensadores.

BRASIL. Código Civil: Lei 10.406, de 10 de janeiro de 2002. In: CURIA, Luiz Roberto; CÉSPEDES, Lívia; ROCHA, Fabiana Dias (Colab.). Vade Mecum. 21. ed. atual. e ampl. São Paulo: Saraiva, 2016.

BRASIL. Código Civil: Lei 10.406, de 10 de janeiro de 2002. São Paulo: Revista dos Tribunais, 2002.

BRASIL. Constituição da República Federativa do Brasil. In: CURIA, Luiz Roberto; CÉSPEDES, Lívia; ROCHA, Fabiana Dias (Colab.). Vade Mecum. 21. ed. atual. e ampl. São Paulo: Saraiva, 2016.

BRASIL. Decreto-lei n. 3.914 de 09 de dezembro de 1941. In: CURIA, Luiz Roberto; CÉSPEDES, Lívia; ROCHA, Fabiana Dias (Colab.). Vade Mecum. 21. ed. atual. e ampl. São Paulo: Saraiva, 2016. 
BRASIL. Estatuto da Pessoa com Deficiência: Lei Brasileira de Inclusão n. 13.146, de 06 de julho de 2015. In: CURIA, Luiz Roberto; CÉSPEDES, Lívia; ROCHA, Fabiana Dias (Colab.). Vade Mecum. 21. ed. atual. e ampl. São Paulo: Saraiva, 2016.

BROWNSWORD, Roger. Bioethics today, bioethics tomorrow: stem cell research and the dignitarian alliance. 17 Notre Dame J. L. Ethics \& Pub. Pol'y, n. 15, p. 15-51, 2003.

CARBONELL, Miguel. Derechos fundamentales y relaciones entre particulares (notas para su estúdio). IUS - Revista del Instituto de Ciencias Jurídicas de Puebla A.C., México, n. 18, p. $50-75,2006$.

CARTÓRIO hoje: serviços de cartório na internet. Revista ANOREG/SP, n. 3, p. 24-29, dez. 2012.

CAULFIELD, Timothy; CHAPMAN, Audrey. Human dignity as a criterion for science policy. PLoS Medicine, v. 2, n. 8, p. 736-8, ago. 2005.

CFM - Conselho Federal de Medicina. Código de Ética Médica. Resolução do CFM n. 1.931/2009. In: FRANÇA, Genival Veloso. Direito médico. 11. ed. rev., atual. e ampl. Rio de Janeiro: Forense, 2013.

CFM - Conselho Federal de Medicina. Resolução n. 1.805/2006. Disponivel em: <http:// www.portalmedico.org.br/resolucoes/cfm/2007/111_2007.htm>. Acesso em: 6 jul. 2015.

CFM - Conselho Federal de Medicina. Resolução n. 1.995/2012. Dispõe sobre as diretivas antecipadas de vontade dos pacientes. Disponivel em: <http://www.portalmedico.org.br/ resolucoes/CFM/2012/1995_2012.pdf>. Acesso em: 6 jul. 2015.

COELHO, Paulo Ulhoa. Curso de direito civil: contratos. 5. ed. São Paulo: Saraiva, 2012.

COMPARATO, Fábio Konder. Fundamento dos direitos humanos. Instituto de Estudos Avançados da Universidade de São Paulo, p. 1-21, 2013.

COSTA, José André da. Ética e política em Lévinas: um estudo sobre alteridade, responsabilidade e justiça no contexto geopolítico contemporâneo. 2011. 206 f. Tese (Doutorado em Filosofia) - Pontifícia Universidade Católica do Rio Grande do Sul, Porto Alegre, 2011.

FERNÁNDEZ DEL CASTILLO, Tomás de la Quadra Salcedo. Derecho público, derecho privado y derechos fundamentales. Revista General de Derecho Administrativo, n. 34, p. 1-66, 2013.

FERREIRA, Paulo Roberto Gaiger. Nova minuta (versão 2012): Escritura Pública de Diretivas Antecipadas de Vontade e Outras Disposições, 2012. 26ํo Tabelionato de notas 12 nov. 2012. Disponível em: <https://www.26notas.com.br/blog/?p=6536>. Acesso em: 7 abr. 2016.

FREITAS, Riva Sobrado de; CLEMENTE, Alexandre Shimizu. A incidência dos direitos fundamentais nas relações privadas. Direitos Fundamentais \& Justiça, ano 5, n. 15, p. 159-185, abr./jun. 2011.

GODINHO, Adriano Marteleto. Diretivas antecipadas de vontade: testamento vital, mandato duradouro e sua admissibilidade no ordenamento jurídico brasileiro. Instituto de Direito Brasileiro, Lisboa, ano 1, n. 2, p. 945-978, 2012. 
GONÇALVES, Carlos Roberto. Direito civil brasileiro - Parte geral. 10. ed. São Paulo: Saraiva, 2012. v. 1.

GUARDIA, Andrés Felipe Thiago Selingardi. A dignidade da pessoa humana: da antropologia filosófica ao Estado Democrático de Direito. Revista Faculdade de Direito da Universidade de São Paulo, v. 109, p. 217-44, jan./dez. 2014.

JONAS, Hans. El principio de responsabilidad: ensayo de una ética para la civilización tecnológica. Introdución de Andrés Sánchez Pascual. Barcelona: Herder, 1995.

KANT, Immanuel. Fundamentação da metafísica dos costumes. Tradução com introdução e notas de Guido Antônio de Almeida. São Paulo: Barcarolla, 2009.

KANT, Immanuel. Metafísica dos costumes. Tradução, textos adicionais e notas de Edson Bini. São Paulo: Edipro, 2003. Série Clássicos Edipro.

LÉVINAS, Emmanuel. Entre nós: ensaios sobre a alteridade. Tradução e coordenação de de Pergentino Stefano Pivatto. Petrópolis: Vozes, 2004.

LÉVINAS, Emmanuel. Otherwise than being or beyond essence. Translated by Alphonso Lingis. Pittsburgh, Pennsylvania: Duquesne University Press, 2006.

MACKLIN, Ruth. Dignity is a useless concept. BMJ, v. 327, Dec. 2003.

MARTINS, Flademir Jerônimo Belinati. Dignidade da pessoa humana: princípio constitucional fundamental. 7. reimpr. Curitiba: Juruá, 2012.

MAURER, Béatrice. Notas sobre o respeito da dignidade da pessoa humana... ou pequena fuga incompleta em torno de um tema central. In: SARLET, Ingo Wolfgang (Org.). Dimensões de dignidade: ensaios de filosofia do direito e direito constitucional. Tradução de Ingo Wolfgang Sarlet. Porto Alegre: Editora do Advogado, 2005.

MEIRELES, Rose Melo Vencelau. Autonomia privada e dignidade humana. Rio de Janeiro: Renovar, 2009.

PERPICH, Diane. The ethics of Emmanuel Lévinas. Califórnia: Stanford University Press, 2008.

RECKZIEGEL, Janaína; CONINCK, Beatriz Diana Bauermann. Entre a vida e a morte: revisitando a morte digna em pacientes terminais. In: MARCO; Christian Magnus de; KRAVETZ, Rafaella Zanatta Caon. Diálogos sobre direito e justiça: coletânea de artigos. Joaçaba: Ed. Unoesc, 2015. v. 1.

RECKZIEGEL, Janaína; PEZZELA, Maria Cristina Cereser. O papel da sociedade tecnocientífica e os riscos decorrentes das pesquisas médicas com seres humanos. Revista Direitos Garantias Fundamentais, Vitória, v. 14, n. 2, p. 101-24, jul./dez. 2013.

SARLET, Ingo Wolfgang. As dimensões da dignidade da pessoa humana: construindo uma compreensão jurídico-constitucional necessária e possível. In: SARLET, Ingo Wolfgang (Org.). Dimensões de dignidade: ensaios de filosofia do direito e direito constitucional. Tradução de Ingo Wolfgang Sarlet. Porto Alegre: Editora do Advogado, 2005.

SARLET, Ingo Wolfgang. Dignidade da pessoa humana e direitos fundamentais na Constituição Federal de 1988. 7. ed. rev. e atual. Porto Alegre: Livraria do Advogado, 2009. 
SCHULMAN, Adam. Bioethics and the question of human dignity. In: SCHULMAN, Adam (Ed.). Human dignity and bioethics: Essays Commissioned by the President's Council on Bioethics. Washington, D.C.: [s.n.], 2008.

SIMÃO, José Fernando. Estatuto da pessoa com deficiência causa perplexidade (parte 1). Revista Consultor Jurídico, p. 1-6, ago. 2015.

STEINMETZ, Wilson. A vinculação dos particulares a direitos fundamentais. São Paulo: Malheiros, 2004.

TARTUCE, Flávio. Direito civil 3: teoria geral dos contratos e contratos em espécie. 7. ed. rev. e atual. São Paulo: Método, 2012.

TARTUCE, Flávio. Manual de direito civil: volume único. 6. ed. rev., atual. e ampl. Rio de Janeiro: Forense; São Paulo: Método, 2015.

Informação bibliográfica deste texto, conforme a NBR 6023:2002 da Associação Brasileira de Normas Técnicas (ABNT):

RECKZIEGEL, Janaína; CONINCK, Beatriz Diana Bauermann. As diretivas antecipadas de vontade como condição para aferir em concreto o morrer com dignidade à luz da teoria da eficácia imediata. Direitos Fundamentais \& Justiça, Belo Horizonte, ano 11, n. 37, p. 241-272, jul./dez. 2017.

Recebido em: 28.03.2017

Pareceres: 25.04.2017, 18.05.2017 e 02.09.2017

Aprovado em: 17.10.2017 